\title{
Andrija Filipović
}

\author{
Fakultet za medije i komunikacije, \\ Univerzitet Singidunum \\ andrija.filipovic@fmk.edu.rs
}

\section{Ontosonografske mape: ka teoretizaciji formi zvučnog okruženja u epohi antropocena}

Apstrakt: U ovom radu ću razmotriti načine na koje se mogu konceptualizovati i mapirati forme zvučnog okruženja u epohi antropocena. Upotrebom pojmova svet, lopta/globus, Zemlja i planeta projektuje se i naročito razumevanje čoveka, okruženja, trenutnog stanja stvari, ali i prošlosti i budućnosti. Za te pojmove vezujem i pojmove koji imenuju različite načine proizvodnje i recepcije zvuka kao i njihove međusobne odnose - biozvuk, zoezvuk, nekrozvuk, geozvuk i petrozvuk. Ovu tipologiju zvuka izvodim na osnovu ontosonografske metodologije i primenjujem na posebne studije slučaja kao što su popularna muzika, zvuk insekata i buka koju proizvodi saobraćaj. Od presudnog značaja za razumevanje antropocenskog zvučnog okruženja ispostavlja se odnos između biozvuka i geozvuka koji se proizvodi kroz petrokulturu kao mnoštvo praksi ekstrakcije i eksploatacije fosilnih goriva. Dominantna ili najintenzivnija forma zvučnog okruženja u epohi antropocena jeste petrozvuk.

Ključne reči: Antropocen, ontosonografija, zvučno okruženje, planeta, petrozvuk

Uvod

Antropocen se u prirodnonaučnim i humanističkim diskursima određuje kao geološka epoha koju suštinski određuje čovek, to jest, ljudska aktivnost. Geološke epohe se u prirodnim naukama određuju po stratigrafskim kriterijumima kao što je prisustvo biljnih i životinjskih fosila ili karakterističnih minerala. Drugim rečima, geološke epohe nastaju usled aktivnosti prirode i/ili planete u smislu taloženja organske i neorganske materije i kretanja tektonskih ploča. U antropocenu, pak, ono što je ranije nastajalo „spontanom“ i ,prirodnom“ aktivnošću, sada nastaje kao posledica ljudske aktivnosti i, u tom smislu, granica između ljudske istorije i neljudskog i između kulture i prirode postaje nejasna jer aktivnost čoveka, odnosno efekat njegovih dela, poprima planetarne razmere (Chakrabarty 2009). Šta je ono što postaje novi antropocenski geološki sloj još uvek nije precizno određeno. Neki naučnici tvrde da je za početak nove epohe 
najbolje uzeti industrijsku revoluciju, kada se započelo sa obimnijom eksploatacijom fosilnih goriva te emisijom gasova staklene bašte, što je dovelo do globalnog zagrevanja. Drugi se zalažu da to bude trenutak Velikog ubrzanja sredinom 20. veka, kada se počelo sa industrijskom proizvodnjom i masovnom upotrebom plastike i plastičnih proizvoda. Treći se, pak, zalažu za datiranje početka nove geološke epohe na trenutak eksplozije prve atomske bombe i eksploataciju nuklearne energije, s obzirom na dugotrajnost nuklearnog otpada. Četvrti tvrde da bi trebalo uzeti početak kolonizacije Severne i Južne Amerike: taj period bio je obeležen velikom migracijom biljnih i životinjskih vrsta i genocidom autohtonog stanovništva, što je dovelo do naglog porasta procenta kiseonika u atmosferi usled brzog pošumljavanja zbog prestanka poljoprivredne aktivnosti što je ostalo zabeleženo u glečerima na polovima (Filipović 2019a). Ovi pregovori oko datuma početka nove epohe od presudnog su značaja jer početak određuje i sveukupni (meta)narativ kao i odabir ontopolitičkih sredstava za opisivanje i pružanje drugačijih pogleda na postantropocensku budućnost.

Antropocen se čuje. Po jednom novijem istraživanju (Duarte et al. 2021), antropogena kakofonija preti okeanskom živom svetu. S obzirom na to da su morski organizmi evoluirali na takav način da se više oslanjaju na zvuk od svojih kopnenih pandana jer se zvuk dalje i lakše prenosi kroz vodu nego kroz vazduh i zemljište, okeanski živi svet ometa buka koju ljudi proizvode. Sve životinje, u rasponu od beskičmenjaka do kitova i delfina koji se oslanjaju na eholokaciju, jesu u opasnosti. Njih ometaju svi antropogeni zvukovi - kako buka koju proizvode brodovi i druga plovna sredstva, tako i sonari i drugi sintetički zvukovi. I ne samo da ih ometaju, nego čak izazivaju i fiziološke promene. Zvučni pejzaž okeana i mora postao je antropocenski, odnosno, postao je radikalno drugačiji od zvučnog pejzaža preindustrijske i preantropocenske epohe. Antropofonija preuzima primat nad biofonijom i geofonijom i u tom smislu je potrebno istražiti koje sve forme zvučnih pejzaža postoje i na koji način učestvuju u (re) produkciji antropocena.

U zavisnosti od toga kako se razumeva okruženje - da li kao svet, Zemlja ili planeta - zavisiće i to šta se čuje, kako se to čuje i šta se s tim zvukom radi i na koji način. Ni svet, ni Zemlja/zemlja, ni planeta nisu jednoznačni termini, čemu u prilog svedoči mnoštvo konceptualizacija tokom istorije (Tusa 2020). Uzmemo li antropogeni zvuk koji je u nekakvoj vezi s planetom, u tom slučaju možemo govoriti o veštini pozvučenja planete s obzirom na to da se planeta, onako kako je razumevam u ovom kontekstu, može čuti u bar dva vida - kroz umetnost organizovanog zvuka (neki žanrovi popularne i vidovi umetničke muzike) i kroz neorganizovani zvuk (zvuk zemljotresa ili, nešto manje katastrofično, vetra ili kiše). Planeta se može čuti kroz organizovani i kroz neorganizovani zvuk, kroz zvuk koji je čovek oblikovao (taj zvuk zovem nekrozvuk), i neoblikovani zvuk koji se proizvodi „u odsustvu“ čoveka i koji je indiferentan prema čoveku (geo- 
$z v u k)$. Zemlja se, s druge strane, čuje isključivo kroz neorganizovani zvuk, zvuk koji proizvode ljudska i neljudska živa bića u svom svakodnevnom životu, u međusobnoj interakciji živih (ne)ljudskih bića ili tih bića sa neživim. Taj zvuk nazivam zoezvukom, od grčke reči za život koji je zajednički svim bivstvujućim - zoe. Na kraju, svet se čuje kroz biozvuk, onaj zvuk koji čovek intencionalno organizuje, što je, najkraće rečeno, popularna i umetnička muzika. Termin biozvuk vezujem za pojam bios, kao zbirni naziv za one tehnike oblikovanja pojedinca i stanovništva specifične za ljudsku zajednicu, što znači da to oblikovanje pojedinca i zajednice funkcioniše i kroz zvuk, ali i da je svet biopolitički proizvod, te da se i on jednim delom proizvodi kroz zvuk.

Svet $=$ biozvuk, Zemlja $=$ zoezvuk, planeta $=$ geozvuk - to je mapa načina na koji se čuje antropocenska epoha. Širi okvir u kojem se javljaju ove pojmovne diferencijacije mogao bi se razumeti kroz formulu koju daje Elizabet Povineli u svojoj knjizi o geontologiji. Ona pokazuje da moramo izaći iz onoga što ona naziva biontološkim okvirom, iz onog metafizičkog okvira koji postavlja život i pojmove razvijene na temelju razumevanja života, $u$ samo središte razumevanja celine bivstvovanja i videti šta znači kada geos postane jedan od ključnih orijentira mišljenja. U tom smislu, ona daje ovu formulu: Živo (Život, rođenje, rast, reprodukcija) v. Smrt) v. Neživo (Povinelli 2016, 9). Živo koje stoji nasuprot Neživom obuhvata i bios i zoe, dok Neživo ima veze isključivo sa geos. Svet i Zemlja čine jedan okvir - Živo - sa minimalnim razlikama koje bios stvara između sebe i zoe u svom samooblikovanju, dok je planeta geos, Neživo kao takvo. Biozvuk i zoezvuk ali i nekrozvuk, jer je smrt samo binarna suprotnost životu, zavise od načina na koje se Živo razumeva i oblikuje, dok geozvuk nastaje u okvirima Neživog. O odnosu Živog i Neživog, kao presudnog za razumevanje petrozvuka i razvijanja drukčijeg pristupa fosilnim gorivima u vreme globalnog zagrevanja i klimatskih promena, pisaću u poslednjem odeljku ovoga rada. Za sada treba napomenuti da se u ovom okviru promišljanja zvučnosti javlja zanimljiv problem odnosa između Živog (koje-nije-ljudsko) i Neživog, zoezuka i geozvuka, zvuka koji proizvode neljudska živa bića i neživa, neorganska planeta u odsustvu čoveka.

S obzirom na to da je i infrazvuk i ultrazvuk (zvuk čije su frekvencije ispod i iznad granica ljudskog domašaja) moguće koristiti u svrhe identifikacije objekata, ontosonografija ide i ispod i iznad ljudskog i u tom smislu je u tesnoj vezi sa pojmom geontologije kako ga Povineli razvija jer oba pojma imaju veze sa onim što je radikalno i apsolutno neljudsko. Dok geontologija otkriva slojeve sedimenata u konstituisanjima postajućih i bivstvujućih, dotle se kroz ontosonografiju obraća pažnja na to šta i kako postoji i postaje putem zvuka i u zvuku. U pitanju nije, na kraju, ontologija zvuka, već ontologija kroz zvuk, pokušaj da se konstruiše ontologija postajućeg i bivstvujućeg sa isključivim naglaskom na ono što se čuje, kroz zvuk koji to postajuće i bivstvujuće proizvodi i kroz koji se 
ono proizvodi. Po analogiji sa geontologijom, kroz ontosonografiju, kao i medicinski ultrazvuk ili sonar, dobijamo eholokaciju različitih postajućih u različitim slojevima ravni imanencije u zavisnosti od toga koliko duboko zvuk može da prodre i na kakve sve materijalnosti može da naiđe ili proizvede. Neka postajuća je lakše eholocirati od nekih drugih. Naime, neka bivstvujuća su izvanredno bučna, toliko da intenzitet zvuka koji proizvode zaglušuje druga postajuća čije zvučne egzistencijalne teritorije bivaju nadglasane i potisnute na margine tih bučnijih teritorijalizacija ili, drukčije rečeno, potisnuta uz zvučni zid tih teritorijalizacija (Filipović 2019b). Ontosonografijom se, dakle, pruža eholokacijski uvid u mnoštvo uodnošenih ritmova postajanja te mapira raspoređivanje intenziteta tih ritmova u slojevima ravni imanencije.

\section{Svet i biozvuk}

Pojam sveta neraskidivo je povezan sa pojmom čoveka, što znači da se način na koji se svet čuje ogleda u pojmu biozvuka, zvuka koji je čovek intencionalno organizovao. Kako pokazuje Mišel Fuko u Riječima i stvarima, moderni pojam čoveka proizvod je 18. i 19. veka. Taj pojam je diskurzivni efekat koji je nastao na preseku jezika, života i rada, tačnije, na preseku modernih nauka - lingvistike, biologije i ekonomije. Pre sloma klasicističke episteme, ,ni sam pojam život nije postojao" (Fuko 1971, 187). U vreme klasicizma i ranije, granice između onoga što danas nazivamo živim i neživim, organskim i neorganskim, povlačile su se na drugačije načine. Tačnije, granica kakvu imamo sada nije ni postojala, već je bila reč o igri sličnosti i razlika koja je sačinjavala kontinuum na kome su se nalazili ljudi, životinje, biljke i minerali. Sa slomom episteme koja je omogućavala prirodnu istoriju, dolazi do oformljivanja moderne biologije koja počinje da funkcioniše po drugačijim diskurzivnim pravilima. Moderna biologija povlači jasne granice između živog i neživog: „Organski postaje ono što je život, a živo je ono što proizvodi, rastući i obnavljajući se; anorgansko je neživo, to jest ono što se ne razvija i što se ne obnavlja; ono je na granici života - inertno i neplodno, to jest smrt" (Fuko 1971, 279). Diskurzivne granice se povlače ne samo između živog i neživog nego i između ljudskog i neljudskog i ,ljudi prestaju da budu nazivani 'ljudskim rodom' i počinju da se nazivaju 'ljudskom vrstom'“ (Fuko 2014, 93). Ljudska vrsta, kao ono što se suštinski razlikuje od drugih vrsta živih bića i neorganske prirode, nastaje usled promena diskurzivnih pravila, a što je imalo svoje uzroke u društvenim i ekonomskim promenama koje su se odigravale u to vreme kada je do ovih promena došlo. Reč je o promeni, sa jedne strane, sa režima suverena na režim biopolitičkog upravljanja, a sa druge, o ubrzanom razvoju i širenju kapitalizma. Ove promene su dovele do izmena u diskurzivnoj proizvodnji pojma čoveka jer je za potrebe biopolitičkog upravlja- 
nja u uslovima kapitalizma bilo potrebno proizvesti stanovništvo kojim se može upravljati različitim tehnikama u rasponu od higijene do statistike. Moderni pojam čoveka, dakle, nastaje kao „ništa drugo do figura stanovništva“ (Fuko 2014, 97) jer, da bi se omogućilo upravljanje stanovništvom, bilo je potrebno oformiti normu, prosečnog čoveka koji će služiti kao ono u skladu sa čim će se svi pojedinci oblikovati kroz brojne vidove (naučnih) disciplina.

$\mathrm{Na}$ ovako proizvedeni pojam čoveka, čoveka kao biopolitički oblikovanog organizma, naslanjaju se dva uvida koji su od interesa za potrebe ovog rada. Prvo, po analogiji sa čovekom kao organizmom koji predstavlja organizovanu i zatvorenu celinu, dobijamo sliku sveta kao ,plavog klikera“, globusa/lopte, sveta kao zatvorene samoodržive celine koja je živa i podložna eksploataciji putem proizvodnje znanja o njoj ili putem trošenja „resursa“ (Colebrook 2014). Ova slika sveta je i jedan od efekata procesâ globalizacije, koji upravo podrazumevaju da je svet kao globus/lopta ne samo dosežan, nego i podložan premeravanju i odeljivanju, kako praktičnom tako i teorijskom. Procesi globalizacije i stvaranje slike sveta kao zatvorene celine počivaju i na još jednoj ontološkoj pretpostavci, a to je da je ta celina jedna, to jest pretpostavlja se ontologija Jednog. Korelat ovom svetu-kao-Jednom jeste efekat globalizacije kao jedinstveni političko-ekonomski sistem (liberalna demokratija i neoliberalni kapitalizam) te jedinstvena transnacionalna kulturalizacija. Drugi uvid leži u tome što se može se govoriti o biozvuku kao biopolitičkoj tehnologiji za proizvodnju i održavanje određene slike čoveka koja je u neraskividoj vezi sa opisanom slikom sveta. Proizodnja čoveka i formi života u odnosu sa zvukom i kroz zvuk te muziku vrši u dva vida - kroz bio-auralne-tehnologije i kroz bio-melo-tehnologije. Pojam bio-melo-tehnologija imenuje upotrebe onoga što se opaža kao organizovani zvuk u formi muzike, dok pojam bio-auralnih-tehnologija imenuje sve one procese koji se tiču oblikovanja neorganizovanog zvuka i o kome će biti više reči u narednom odeljku. Bio-melo-tehnologije, dakle, tiču se načina oblikovanja i odnošenja prema zvuku u svetu i proizvodnji tog sveta kroz bio-melo-tehnologije. Ovde je, dakle, reč o proizvodnji sveta kroz organizovani zvuk, kako kroz popularnu, tako i kroz umetničku muziku.

Biozvuk, kao zvuk koji je organizovan kroz bio-melo-tehnologije, može se analizirati kroz popularne hit pesme. Peter Sendi povezuje osećanja, pamćenje i sopstvo pri slušanju hitova i kaže da se intimna osećanja koja se javljaju pri tim slušanjima proizvode kao klišei. Hitovi su „ono što je najbanalnije na tržištu muzičke robe, što je najrazmenljivije u kruženju razmene. Ukratko, ovi hitovi su toliko nalik nama i tako nas jasno okupljaju jer su posve slični“" (Szendy 2012, 65). Kroz slušanje hitova vrši se naročita subjektivizacija koja izjednačava komodifikaciju proizvoda popularne muzike i proizvoda biopolitike. Bio-melo-tehnologija hit pesme je tehnologija egzistencije i kao takva je tehnologija za proizvodnju subjekta koji stvara pojedinca i zajednicu (slušalaca), 
koja je paradoksalno jedinstvena i repetitivna. S jedne strane, pojedinac postaje sentimentalni subjekt potrošnje time što uvezuje hit sa vlastitim sećanjem i osećanjima, s druge strane, kroz stvaranje kolektiva i grupa okupljenih oko slušanja i praćenja određenog izvođača, grupe ili žanra. U oba slučaja, na delu je bio-melo-tehnologija proizvodnje subjekta.

S obzirom na to da se popularna muzika može analizirati na ovaj način - kao specifični vid subjektivizacije, onda je moguće sprovesti i jednu analizu načina proizvodnje različitih subjekata u zavisnosti od toga kakva muzika se sluša. Uzeću za primer pesmu „Constant Craving“ $k$. $d$. lang i obradu te pesme koju su uradile Lesbians of Ecstasy pod nazivom „Kundstant Krøving“. Po Halberstam (Halberstam 2011), k. d. lang kroz virtuozitet i kroz baršunasti, duboki glas evocira sentimentalnost koja je najpodložnija komodifikaciji, upravo na način na koji o tome piše Sendi. Međutim, Lesbians on Ecstasy odbijaju sentimentalizaciju zajedno sa komodifikacijom. Dok kod $k$. $d$. lang neprestana žudnja ostaje zauvek nezadovoljena, kod Lesbians on Ecstasy ta žudnja postaje destruktivna i usmerena ka klišeu kojim se $k$. $d$. lang u ovoj pesmi služi. Destrukcija klišea kroz obradu upućuje antikonzumerističku poruku koja je upravljena protiv proizvodnje potrošačkog subjekta. U ova dva pristupa istoj pesmi imamo i dva pristupa u proizvodnji subjekta kroz bio-melo-tehnologije. S jedne strane, $k$. d. lang proizvodi sentimentalne, komodifikovane subjekte poznog liberalnog kapitalizma podstičući afektivnu identifikaciju sa klišeom i žudnjom čije se zadovoljenje odlaže čime se i ciklus potražnje i potrošnje neprestano obnavlja. S druge strane, Lesbians on Ecastsy pokazuju da je moguće razlančati uvezanost osećanja, sećanja, doživljaja, tela, subjekta i kapitala tako što će se klišeizacija na kojoj ta ulančanost počiva temeljno razrušiti kroz preradu. Lesbians on Ecstasy pokazuju da je subjekt moguće proizvesti na temelju potrošačkog subjekta ali takav subjekt koji neće biti potrošačko-sentimentalni, već će ukazivati na drugačije temporalnosti. Poenta ovog kratkog razmatranja načina na koji se subjekti proizvode kroz popularnu muziku leži u tome što pokazuje da se različiti subjekti mogu proizvoditi na osnovu muzičkog materijala i to tako da ti subjekti podrazumevaju različite društvene pozicije kao i ontološke pretpostavke. Dok „Constant Craving“ zahteva subjekta koji će linearno slediti svoju (potrošačku i nikad zadovoljenu) želju, dotle „Kundstant Krøving“ proizvodi subjekta na osnovama koje ukazuju na radikalno otvorenu budućnost kao utopijsku projekciju društvenosti. Rečju, bio-melo-tehnologijom se proizvode različiti svetovi. Kroz zvuk koji je organizovan putem bio-melo-tehnologije čuju se svetovi sa specifičnim ontološkim strukturama.

Svet se javlja kroz organizaciju zvuka koja je izvršena kroz bio-melo-tehnologije. Kako se u tom okviru čuje antropocen? Kako se u svetu koji je oblikovan kroz biozvuk čuje nova geološka epoha? Kakva je struktura sveta koja se nudi kroz pozvučenje antropocena? Pišući o načinima na koji hiperobjekt obavija 
ljude, Timoti Morton kaže da se viskoznost hiperobjekata nalazi u njihovom delanju. Hiperobjekti su „demonski, u smislu da obuhvataju svetove i vremena, kao fiberoptički kabolovi ili elektromagnetska polja. I demonski su u tom pogledu da kroz njih kauzalnosti teku kao električna struja“ (Morton 2013, 29). To ga vodi tvrdnji da je ono što je Sokrat nazivao daimonom za nas danas elektromagnetni talas ,koji pojačava okidanje gitarske žice i prenose ga kroz opremu... a od početka Velikog Ubrzanja (1950), ovi demonski kanali su postajali sve moćniji i moćniji“ (Morton 2013, 29). Zatim Morton prelazi na opis slušanja „My Bloody Valentine“ i kaže sledeće: „Kada slušam My Bloody Valentine, ne posežem za zvukom - umesto toga, mene iznutra napada pulsacija koja je i zvuk, fizička sila koja me gotovo podiže sa poda... Akordi mučno bauljaju jedan oko drugog, uklizavajući u i isklizavajući iz melodije, nakupljajući visine harmonija kroz disonancu. Distorzija mrvi i fragmentira zvuk u valjanje šljunka i guste nafte... Muzika je tako lepa“ (Morton 2013, 29). Za glas pevačice kaže da ga jedva čujemo, „kao da njen glas sadrži hiperobjekt, kuljanje, mučna proklizavanja, teturanja i bombardovanje gitarom. U ovom smislu muzika My Bloody Valentine je potpunije ekološka nego predstavljačka muzika 'prirode' i beskompromisnija od tihe ambijentalne muzike“ (Morton 2013, 30). Ogromnost i sveobuhvatnost muzike koju stvara „My Bloody“ Valentine ukazuje na viskoznost hiperobjekta te na antropocenski uslov savremenosti.

Judžin Taker, kroz biozvuk koji je postao nekrozvuk, čuje planetu kao takvu. Kroz black metal muziku, tvrdi Taker, čuje se svet-bez-nas, svet koji je postojao pre čoveka i koji će postojati pošto čovek bude nestao kao vrsta. Razmatrajući značenje termina black u black metalu (doslovno prevedeno znači crno), Taker ukazuje na mogućnost da se to black razume ne kroz satanizam niti kroz (neo) paganizam - što su dva svetonazora koji se najčešće povezuju sa black metal muzikom - jer su oba odveć antropocentrična, već kroz kosmički pesimizam. Kosmički pesimizam za Takera označava „nemoguće mišljenje izumiranja bez ijednog jedinog ljudskog bića da misli odustvo svih ljudskih bića, bez ikakve misli da misli negaciju celokupne misli. Otuda drugačije moguće značenje termina 'black': Black=Kosmičko. Ili bolje, Black=Kosmički pesimizam“" (Thacker 2011). Kosmički pesimizam se može čuti u radovima grupe Sunn O))) (album Grimmrobe Demos iz 1999) i Wold na albumu Stratification iz 2008, ali najneposrednije u radu japanskog umetnika Keiđija Hainoa koji ni ne pripada žanru metal muzike. Taker analizira njegov album So, Black is Myself iz 1997. godine koji se sastoji iz jednog jedinog stiha u svojih 70 minuta - „Wisdom that will bless I, who live in the spiral joy born at the utter end of a black prayer", jedina „muzička“ pratnja su generator tona i glas. Taker na sledeći način opisuje ovaj rad: „Hainov glas se prostire preko celog tonalnog spektra od gotovo subharmonijskih napeva do zazornog falseta koji proizvode izgladnele vile“ (Thacker 2011). Haino izražava bezlični afekt koji je metafizička negacija, nihil 
negativum, i na kraju čak negira i samoga sebe u ,nekoj vrsti muzičke antiforme“" (Thacker 2011).

Nekro u nekrozvuku kao onom zvuku u kom se, kroz biozvuk - zvuk koji je intencionalno proizveo čovek, čuje planeta koja poseduje specifično značenje. Taker kaže da je u klasično doba nekros imalo bar dva značenja. Prvo se odnosilo na leš ili mrtvo telo, dok je drugo značenje se nalazi u konceptu mrtvih kao onoga što je umrlo ali je na neki način vitalizovano, život-posle-života. Život-posle-života mrtvih, nekros u drugom značenju, jeste noumenalni život, „konceptualni prostor koji nije ni ono što se živi izvan diskursa, niti ono što se misli unutar diskursa ali ne neživljeno. Mi ćemo ovo zvati 'horor života'... ako je život-posle-života noumenalni život, on je to jer izaziva noumenalni horor koji je horor života koji indiferentno nastavlja da živi“" (Thacker 2011). U poslednjoj instanci, nekros je život-bez-bivstvovanja koji je nemoguće misliti, ali koji je moguće prikazati putem horora, kako filmskog, tako i muzičkog. U tome leži i horor izumiranja, ali izumiranja koje se konceptualizuje kao praznina, „biološka praznina, forma života koja nije ni biološki život (smrt organizma), niti egzistencija skupa (istrajavanje vrste). U izumiranju, skup je u odnosu prema životu načinom na koji smrt života vodi do praznine ili praznog skupa. Izumiranje je prazni skup biologije... Izumiranje je ne-bivstvovanje života koje nije smrt" (Thacker 2011).

Kroz ova tri vida popularne muzike imamo i tri pristupa svetu. Prvi, koji sam analizirao kroz upoređivanje $k$. $d$. lang i Lesbian on Ecstasy, pruža nam sliku sveta koja je zasnovana na potrošačkom kapitalizmu i, samim tim, na svetu koji je globus/lopta premrežena transnacionalnim kapitalizmom u okviru kojeg mi postajemo subjekti isključivo kao subjekti konzumiranja standardizovanih (klišeiziranih) proizvoda, uključujući i proizvode popularne kulture. S druge strane, Lesbians on Ecstasy nam nudi mogućnost drugačije proizvodnje subjekta koja bi bila usmerena na kritiku takve slike sveta i koja reorganizuje temporalnost na takav način da je proizvodnja subjekta usmerena na utopijski aspekt budućnosti. U slučaju „My Bloody Valentine“, kroz njihovu muziku čujemo viskoznost hiperobjekta, a hiperobjekt je globalno zagrevanje i, samim tim, antropocen. Kroz proizvod popularne kulture, ponešto alternativan u odnosu na mainstream produkciju, čujemo ljudski svet ali i onaj svet koji trpi posledice ljudske aktivnosti. Sve ovo čujemo kroz specifičan način proizvodnje muzike koji poseduje „My Bloody Valentine“, a koji otkriva viskoznu prirodu hiperobjekta. U poslednjem primeru, kroz organizovani zvuk, kao što su black metal i noise, čujemo planetu kao takvu koja postoji u odustvu svega ljudskog. Takav zvuk nazivam nekrozvukom jer planeta podrazumeva u svojoj konceptualnosti izumrlost ljudske vrste i odsustvo svakog ljudskog vida mišljenja. Na kraju, kroz biozvuk dobijamo bar tri načina percipiranja, odnosno tri relacione strukture sveta: svet kao globus/loptu, svet u odnosu sa Zemljom i svet u odnosu sa planetom. 


\section{Zemlja i zoezvuk}

Zemljom nazivam ono što je živo i što ne uključuje nužno čoveka. U tome sledim formulu koju je dala Povineli i o kojoj sam više pisao u uvodom delu ovog poglavlja: Živo (Život(rođenje, rast, reprodukcija)v.Smrt) v. Neživo. Život „kao takav“ i ono što je živo, međutim, uopšte nije jednostavno odrediti. Tako jedan udžbenik iz biologije na samom početku kaže da živi organizmi dele mnoge karakteristike koje se ne nalaze u neživom svetu i te karakteristike podrazumevaju da se živa bića sastoje od jedne ili više ćelija, sadrže genetičku informaciju, koriste genetičku informaciju da se reprodukuju, genetički su povezana i evoluirala su, mogu da konvertuju molekule koji su uzeli iz svoje okoline u nove biološke molekule, mogu da ekstrahuju energiju iz okoline i upotrebe je u biološkom radu, mogu da regulišu svoju unutrašnju okolinu (Sadava et al. 2011, 3). Međutim, autori se, odmah nakon izlistavanja ovih karakteristika, ograđuju tvrdeći da, recimo, seme neke biljke može godinama da prebiva u pustinji a da ne „ekstrahuje energiju iz okoline, konvertuje molekule, reguliše unutrašnju okolinu ili da se reprodukuje pa je ipak seme život" (Sadava et al. 2011, 3). Oni dodaju i da se virusi ne ,sastoje od ćelija i da nemaju vlastite fiziološke funkcije... Ipak, virusi sadrže genetičku informaciju i zasigurno mogu da mutiraju i da evoluiraju“ (Sadava et al. 2011, 3). I, uprkos ovome, naredni odeljak počinje podnaslovom „Ćelije su osnovne jedinice života“. Kontradikcija sustiže kontradikciju u pokušaju da se odrede život kao takav i pojedinačna bića koja su u nekakvoj vezi sa nekako definisanim pojmom života, a razloge za kontradikciju treba potražiti u filozofskoj istoriji pojmova života i živućeg.

Po Judžinu Takeru, tokom istorije filozofije razvilo se nekoliko temeljnih konceptualizacija života koje su se prelivale i na druge, regionalne discipline, kao što je to pomenuta biologija. Ključno je to da se pojam života razvijao u terminima nečega drugog od života, kaže Taker, i predlaže tri velika okvira - život definisan terminima vremena i temporalnosti (,superlativni život"), život definisan terminima forme i svrhovitosti (,univokna stvorenja“) i život definisan terminima duha i imanencije (,mračni panteizam“) (Thacker 2010, xii). Kada se posmatra u okvirima kontradikcije, život se vidi kao afirmacija i negacija kada se konceputalizuje spram vremena, kao aditivan i subtraktivan kada se konceptualizuje kao forma i, na kraju, kao unutrašnjost i spoljašnjost kada se određuje kao duh (Thacker 2010, xiii). Dalje u ovom odeljku ću eksplicirati ove koncepcije života i živog, te istražiti kako se život određen kao imanencija čuje i koje se tehnologije za oblikovanje i upravljanje živim mogu naći u proizvodnji zvuka kroz imanentni život. U najkraćem, život kao imanencija (Zemlja) čuje se kao zoezvuk, a oblikuje se zoe-auralnim-tehnologijama.

Prva konceptualizacija života u najširem smislu jeste određivanje života u njegovom odnosu prema vremenu i temporalnosti, život kao superlativni život. 
Život se određuje kao „nešto što je velikodušno, produktivno, proliferativno i začinjuće. Život je ono što teče ili ističe - bilo da se postavi transcendenti izvor tog isticanja ili da život-kao-proces jednostavno teče iz samoga sebe" (Thacker 2010, 26-27). Druga pretpostavka superlativnog života glasi da je ,velikodušnost života kao takva nesvodiva i neograničena, mada partikularna ispoljavanja života mogu biti ograničena. Bilo da se postavi 'životna sila', 'Sve-Duša', elan vital ili emergentna svojstva, postoji nešto, neki Život, koji uslovljava mogućnost uslovljenog ili živućeg - čak iako je uslovljavajući princip kao takav u potpunosti imanentan uslovljenom“ (Thacker 2010, 27). Treći uslov je da život mora biti distributivan, sveobuhvatan i ističući, to znači da je život ,istovremeno svuda i nigde, čist višak i velikodušnost, a ipak po sebi niti jedna jedina individualna instanca života“" (Thacker 2010, 27). Superlativni život je život koji je neiscrpan i sveprisutan, ali koji, dok se u svojoj prisutnosti ogleda u pojedinačnim živim bivstvujućima, ipak ne iscrpljuje u njima. Život kao superlativan neprestano teče iz samoga sebe prevazilazeći svaku svoju pojedinačnu manifestaciju. Iz ovakve koncepcije života, života kao velikodušnog samodavanja, života kao dara/poklona, sledi puno problema, naročito kada je reč o odnosu života-kao-prinicpa-samodavanja i života-kao-samodatog-pojedinačnog. Ovaj prvi život je život kao transcendentalni i/ili transcendentni princip, dok je ovaj drugi život kao efekat tog principa (razlika). U osnovi je reč o toku jednog principa i uzroka u njegovoj transformaciji u efekat i posledicu. Time dolazimo do problema života razumevanog u okvirima vremena, s obzirom na to da je ovde reč o toku kao postajanju i promeni.

Druga koncepcija počiva na pojmovima forme i svrhovitosti (,univokna stvorenja“") i sledi iz prethodnog uvida da je odnos između života i živućih problematičan, to jest, da sledi da život uveliko prevazilazi i određuje same granice mišljenja. Taker se pita kako ideja superlativnog života uslovljava uvezivanje između života i živućih i iz tog pitanja izvlači nekoliko dimenzija - odnos između ontološkog temelja i onoga što se utemeljuje (život kao pojam koji je nužan za mišljenje živućeg), uzročni odnos po kome princip kauzalnosti strukturiše ono što postoji (život obuhvata uslovljava stvaranje živućeg), proces stvaranja koji određuje odnos između života i živućeg. Termin stvorenja u sintagmi „univokna stvorenja“, Taker koristi ciljajući na stari teološki problem odnosa između božanskog i stvorenog, pri čemu su to dva radikalno različita sveta. Reč je o pitanju odnosa između dva termina i posredovanja između njih. Pitanje stvorenja je pitanje odnosa forme i svrhovitosti zato što „kada se pojam života misli u terminima stvoritelja, stvorenog i stvorenja, život se javlja u dva vida: život-koji-je-formiran i život-koji-formira“" (Thacker 2010, 99). Život koji je formiran je ,formiran u različitim formama života koji nam daju stratifikacije biljnog, životinjskog i ljudskog života. U bitnijem smislu, život je sam princip kojim te forme života poprimaju formu. Ovde život nije ni individualizovano 
živo biće, niti čak šire kategorije (kao što je to vrsta) unutar kojih su ta bića smeštena. Život u ovom drugom smislu je više nalik životu-koji-formira, život koji sam proizvodi raznolike životne forme“ (Thacker 2010, 99). Problem koji se ovde javlja ogleda se u pitanju šta je forma forme, stvaranje stvorenog, to jest šta je život živućeg. Odgovor koji se nudi jeste univoknost, te otuda Takerovo „univokna stvorenja“. Univoknost odgovara na problem odnosa odnosa, odnosa između života i živućeg, stvoritelja i stvorenja, to jest života odnosa između života i živućeg ili stvaranja između stvorenja i stvoritelja. Drugim rečima, potrebna je neka vrsta kontinuiteta između života i živućeg a da taj kontinuitet nije ni realni ni formalni identitet. Univoknost ili jednosmislenost imenuje ,istu prirodu“, tačnije ,prirodu svih zajedničkih priroda“ u smislu da svako bivstvujuće poseduje bar neki zajednički aspekt koji deli sa nekim drugim bivstvujućim počevši od „ovosti“ kao individualizujućeg prinicpa pa sve do vrste, roda ili nekog drugog skupa (Thacker 2010, 123). Iz ovog stava o univoknosti-jednosmislenosti sledi da su život i živuće istovremeno odvojeni (zbog „ovosti“), ali da dele i nekakvu zajedničku prirodu. Život učestvuje u živućem upravo kroz odnos univoknosti. Drugi mogući odnosi su analoški i ekvivokni, a ovaj poslednji podrazumeva radikalnu razliku između uzroka i posledice, dok prvi podrazumeva samo posrednu vezu. U tom pogledu, panteizam je granica s kojom se suočava mišljenje univoknosti, što Žil Delez pretvara $u$ formulu pluralizam $=$ monizam u Tisuću platoa, a u Razlici i ponavljanju tvrdi da je bivstvovanje oduvek i bilo jednosmisleno/univokno ali na taj način da se za njega izriče razlika po sebi, što onda vodi ontologiji procesa i postajanja.

Poslednji stav, koji se nadovezuje na pitanje odnosa između života i živućeg kao univoknosti, i koji direktno sledi od tako postavljenog odnosa, jeste ono što Taker naziva „mračnim panetizmom“. To postaje pitanje kontinuuma između života i živućeg, imanencije koja konstituiše ova dva termina i koja se konstituiše između ova dva termina. Iz ovako shvaćenog pojma imanencije onda će proizaći i načini oblikovanja života i živućeg kroz zvuk kao imamenciju. Život kao imanencija je ,život koji se organizuje i samo-organizuje, koji se raspršuje i koji je kao takav pervazivan - život kao organizacioni i topološki, istovremeni sveprisutan pa ipak nematerijalan; na ovaj pojam života možemo referisati u terminima duha“ (Thacker 2010, 160). Kako Taker kaže ,pojam Života je istovremeno ono što je mišljenje po sebi, transcendentno prema partikularnim manifestacijama u živućem, ali i ono što prolazi kroz njih, što prelazi preko njih, što jeste ona - 'zajedničko' koje je i sve individuacije. Život, u okvirima duha, istovremeno je sveprisutan ali je i po sebi, nemanifestovan, 'nepostojeći'. Njegov odnos je kroz negaciju; ono što se misli preko negativnog odnosa između Života i živućeg. Kada se razmatra kroz ontološke (ili onto-teološke) okvire duha, Život je istovremeno transcendentan - razlikujući se od onoga što je manifestovano, i imanentan - dostuan mišljenju samo kada se pojmi kao neodvojiv 
od svojih manifestacija ili 'izraza'“ (Thacker 2010, 160-161). Primera radi, kod nekih srednjovekovnih teologa, život se posmatra dvostruko - kao „univerzalni život" koji ontološki utemeljuje individualizovane organizme i život vrsta, ali je određen i kao dinamični proces koji podrazumeva rast i raspadanje. Ova dva vida podrazumevaju kontinuum, ,vertikalni kontinuum života po osi organizam-vrsta-univerzalni život, i horizontalni kontinuum po kojem život operiše kao biološki i kao nekrološki“" (Thacker 2010, 180). U skladu sa tim, moguće je govoriti o apsolutnom panteizmu, u kome je reč o „vertikalnoj imanenciji“ po kojoj su Bog i priroda identični, kao i o kontrahovanom panetizmu kod koga je reč o horizontalnoj imanenciji, ,imanenciji svake stvari kao svake stvari““ (Thacker 2010, 205), gde je priroda samoemergentna i koekstenzivna sa samom sobom.

Ovime se dolazi do uvida da su moderna i savremena shvatanja života i živućeg određena horizontom mogućih odnosa između života i živućeg, da sama razlika između ta dva te konceptualizacija mnoštvenih mogućih odnosa između i oko njih jesu ono što određuje horizont mišljenja o ovom problemu. To je upravno ono na što ukazuje Povineli kroz formulu koja suprotstavlja Živo i Neživo. Ali, s druge strane, u savremenim promišljanjima o ovom pitanju, granice između Živog i Neživog, života i živućih, nisu tako jasno povučene. To, recimo, možemo videti u anorganskom vitalizmu Deleza i Gatarija. Pozivajući se na profesora Čalendžera, lika iz priče Konana Dojla, koji je naterao Zemlju da vrišti bušeći njenu koru (Deleuze i Guattari 2013, 49), Delez i Gatari razvijaju celu jednu geofilozofiju koja se bavi najrazličitijim stratifikacijama, u rasponu od molekularnih slojeva preko fizičkih i geoloških do onih slojeva koji se stvaraju u nematerijalnom ali jednako realnom sloju kulture. Delez i Gatari, dakle, razvijaju specifični tip vitalizma koji nema veze sa biološkim niti hilomorfičkim modelom živoga, već sa mašinskim, netelesnim i virtuelnim, imanencijom kao životom, kako to Delez u svom poslednjem tekstu kaže. Delez (Delez 2011, 10-12) piše da ćemo

...o čistoj imanenciji reći da je ŽIVOT i ništa drugo... neki život, pri čemu je neodređeni član obeležje onog transcendentalnog... Život je svugde, u svim momentima koji prožimaju određeni živi subjekt i koji odmeravaju određene proživljenje predmete: imanentni život koji odnosi prevagu nad događajima ili singularnostima koji se samo aktuelizuju u subjektima i objektima. Sam taj beskonačni život nema momente, ma koliko oni bili bliski jedni drugima, već samo među-vremena, među-momente. On ne iskrsava, niti zauzima mesto, već predstavlja ogromnost praznog vremena u kojm se vidi događaj još u dolasku i događaj koji se već dogodio... Život sadrži samo virtuelnosti.

Odredi li se odnos između života i živućeg kao imanentan, što je, pokazalo se, jedan od glavnih načina promišljanja odnosa između ova dva termina, zapitaćemo se kakva je to imanencija. Kao što se pokazalo, ta imanencija može biti 
hijerarhijska i vertikalna ili horizontalna i nehijerarhijska. Horizontalna imanencija se može promišljati na bar dva načina - po uzoru na živa bića, te će u tom smislu sve biti na neki način živo i sve će se razmatrati u okvirima organizma (hilomorfizam) ili će model biti anorgansko-vitalistički po kome aktivnost (ne) telesne materije sledi drukčiju logiku od hilomorfističke. Ali ova dva modela imanencije postaju neoperativna kada se uzme imanencija zvuka. Kada počnemo da osluškujemo Zemlju kao ono što je živo, imanencija Zemlje koju čujemo navodi nas na zaključak da su granice koje uspostavljamo zapravo proizvedene kao ontopolitički projekti. Naime, granice između različitih živih bića te između živih i neživih bića proizvode se sa određenim ciljem, i to ne samo da bi se povukle nekakve granice, već da bi se bića putem povlačenja tih granica proizvela kao takva. Sve te načine, tehnike i strategije proizvodnje bivstvujućih kroz zvuk nazivam zoe-auralnim-tehnologijama. Zoe kao život zajednički za sva živa bića, život kao takav, diferencira se putem tih tehnologija.

Poslednjih godina, na različitim internet portalima, svakog se leta javljaju tekstovi o takozvanim smrdibubama, a najčešće o takozvanim kineskim smrdibubama (Alyomorpha halys). Tako u jednom tekstu o njima autorka piše: „Iz godine u godinu čini se da ih je sve više. Smrdibube je zaista teško ne primetiti, jer dok lete proizvode nesnosan zvuk, a i miris koji ispuste kada ih ubijete nije ništa prijatniji, zbog čega su u narodu i dobile ovo ime" (Podraščanin N/A). Kao što se vidi, autorka naglašava materijalnost prisutnosti ovog insekta kroz zvuk koji on proizvodi dok leti. Ne samo da je problem koji kineske smrdibube stvaraju onaj olfaktorne prirode kada se dodirnu, nego proizvode iritaciju i putem zvuka. Telo insekta nije samo smrdljivo telo, te, samim tim, „odvratno“, već je i zvučno telo, i to iritabilno zvučno. Ovaj tekst je objavljen na portalu Lepa\&Srećna u sekciji „Moj stan“ i podsekciji „Srećni dom“. Kineska smrdibuba, određena samim svoji imenom kao rasno drugačija i kao invazivna zbog svog porekla i odsustva „prirodnih“ predatora u prirodnoj sredini Republike Srbije, predstavlja pretnju svojom smrdljivošću i bučnošću po „moj“ stan i po „srećni“ dom. Invazivnost ovog tela je materijalno-semiotički proizvedena na više nivoa - vrsnom (kao razlika između insekta i čoveka), rasnom (kao razlika između Kineza i Srba), telesnom (kao razlika između smrdljivog i mirisnog) te zvučnom (kao razlika između bučnog i tihog). Ovime se uspostavljaju materijalno-semiotički lanci koji uvezuju, s jedne strane, čoveka, Srbina, mirisno i tiho (stan/dom), a s druge strane insekta, Kineza, smrdljivo i bučno (divljina).

Slično je i sa komarcima, onim „običnim“, a čak i više s onima koji prenose virus Zapadnog Nila. U slučaju komaraca i zujanja koje označava njihovo prisustvo, načini ophođenja prema ovim insektima, kao i sama proizvodnja razlike između ovih insekata i ljudi, podrazumeva zoe-političke tehnike hemijske kontrole i istrebljivanja (u ovom pogledu bi trebalo govoriti o životinjskim nekropolitikama), navodno u cilju sprečavanja širenja virusa Zapadnog Nila. Ono 
što ove tehnike kontrole i istrebljivanja komaraca pokazuju jeste stanje urbane infrastrukture kao jednog od ključnih uslova za materijalizaciju tela komaraca, kao i prepletene diskurse o finansijalizaciji životne sredine, „evropeizaciji“ društva i (neo)liberalizaciji ekonomije. Kako se može videti iz izveštaja Instituta za javno zdravlje Srbije, Dr Milan Jovanović Batut, iz 14.8.2018. najveći broj komaraca u kojima je potvrđen genom virusa Zapadnog Nila zabeležen je u opštini Palilula koja obuhvata brojna naselja koja ne samo da su većim delom pored reke, nego su i infrastrukturno u lošijem stanju od drugih delova grada. Za razliku od Palilule i još nekih drugih naselja, primera radi, u centralnim opštinama kao što su Savski venac i Stari grad pronađen je najmanji broj ovakvih komaraca. Može se zaključiti da je pitanje infrastrukture od presudnog značaja, tim pre što, kako i piše u preporuci Instituta, treba isušivati izvore stajaće vode, a to su „saksije za cveće, posude za hranu i vodu za kućne ljubimce, kante, burad i limenke... odbačene gume i drugi predmeti koji mogu da prikupljaju vodu“ (Batut 2018). Zanemarimo li cveće i kućne ljubimce, može se reći da naselja sa najvećim brojem komaraca imaju problem kako sa barama, kanalima i drugim otvorenim stajaćim vodama, tako i sa otpadom u vidu kanti, buradi i limenki.

Ovo stanje $u$ infrastrukturi posledica je neodržavanja onoga što je izgrađeno tokom socijalističke Jugoslavije ali i gradnje bez ikakvog urbanističkog plana, što je karakteristika upravo ovog postsocijalističkog stanja u kome se tokovi privatnog kapitala slabo ili nikako ne kontrolišu a zakoni i propisi teško sprovode. U ovakvom stanju stvari pojavljuje se postsocijalistički komarac kao materijalno-semiotičko čvorište mnoštva istorijskih, ekonomskih, urbanističkih i drugih okolnosti, odnosa i događaja. Komarac otkriva načine na koje se određeni delovi grada održavaju ili ne održavaju - dakle, stepen ulaganja novca kako u javno tako i u privatno vlasništvo. Komarac i njegovo zujanje otkrivaju i diskurs finansijalizacije životne sredine kao javnog prostora, s obzirom na to da uklanjanje ili, bar, kontrola komaraca podrazumeva uređivanje javnih površina. Javne površine koje se ne održavaju postaju staništa komaraca, a kako se komarci opažaju kao štetočine i kao pretnja po reprodukciju, samim tim i te javne površine postaju „divlja“ i ,zagađena“ priroda nasuprot dobro uređenoj urbanoj sredini (bez komaraca). Postsocijalistička „divlja“ priroda postaje onoliko uređena životna sredina koliko se novca u nju uloži. A da bi se u nju novac ulagao potrebno je sprovesti ekonomske, političke i društvene reforme da bi se privukle investicije i kapital. S druge strane, da bi se privukle investicije i kapital potrebno je deregulisati tržište, privatizovati državnu svojinu, prekarizovati radnu snagu - rečju, (neo)liberalizovati ekonomiju. U ovom tranzicionom okviru postsocijalizma, u kretanju od „divljine“ prema „čistoj“ $i$ „,nezagađenoj“ životnoj sredini, ka „uređenom“ evropskom društvu i državi, materijalizuje se postsocijalistički komarac kao čvorište mnoštvenih istorijskih, ekonomskih, političkih i društvenih materijalno-semiotičkih tokova (Filipović 2019b). 


\section{Planeta i geozvuk/petrozvuk}

U prethodnom odeljku razmatrao sam odnos Zemlje i zoezvuka. Zemlja je imenovala ono živo, život kao takav koji se čuje kroz pojedinačna živa bića i njihov svakodnevni život i koji se oblikuje kroz zoe-auralne-tehnologije. Planeta se čuje kroz geozvuk. Planetom imenujem planetarnost kao takvu, ono što je zajedničko planetama kao kosmičkim telima nalazila se ona u ovom Sunčevom sistemu ili nekom drugom. Iz te perspektive, planeta nije nešto što je specifično povezano sa uslovima života na Zemlji, niti ima ikakve veze sa životom kakav se razvio na ovoj planeti. Tačnije, planeta ne zahteva nikakav život, tim pre što, bar za sada, nije pronađen nikakav trag života na drugim planetama, te se ovaj fenomen može smatrati nesuštinskom karakteristikom planeta. Planeta je, dakle, ono što je zajedničko svim planetama bez obzira na to da li na njima postoji život ili ne. Geozvuk u tom pogledu imenuje one zvukove koji nastaju aktivnošću same planete. Takvi zvuci su, primera radi, kretanje tektonskih ploča (kod onih planeta koje su geološki aktivne), vetar i kretanje atmosferskih gasova (kod onih planeta koje poseduju atmosferski omotač), zvuk kiše i drugih padavina, zvuk magnetosfere, i tako dalje. U pitanju su zvuci koji nastaju spontanom geo-atmosferskom aktivnošću planete i koji nemaju nikakve veze sa onim živim te samim tim ni sa čovekom. Geozvuk nastaje izvan podele na subjekt i objekt. Može se reći da geozvuk pretpostavlja odsustvo subjekta, u smislu da subjekta nikada nije ni bilo (na planetama gde nema života), ili da subjekta neće biti (posle izumiranja ljudske, a potom i svih životinjskih i biljnih vrsta na Zemlji). Planeta kao kosmičko telo, a sa njom i geozvuk, jeste arhifosil u smislu kako taj pojam koristi Kenten Mejasu u kritici onoga što on naziva korelacionizmom.

Mejasu korelacionizmom naziva onaj filozofski stav koji se „sastoji od isključivanja svake tvrdnje da je moguće razmatrati područja subjektivnosti i objektivnosti nezavisno jedno od drugog“ (Mejasu 2014, 16). U okvirima korelacionizma, nije moguće ni zamisliti ni konceptualizovati objektnost objekta kao takvu bez ikakve veze sa subjektom. Onog trenutka kada se (nešto) misli, po korelacionistima (a korelacionisti su gotovo svi filozofi od Kanta do danas), nemoguće je misliti a da subjekt ne misli nekakv objekt. Jedino se kroz subjektovo mišljenje objekt daje subjektu. Mi nikada nemamo objekt kao takav, objekt po sebi, bez objektovog uodnošavanja sa subjektom. Ključno je ,vjerovanje u prvenstvo relacije nad povezanim terminima; vjerovanje u konstitutivnu moć uzajamne relacije“ (Mejasu 2014, 16). U toj primarnoj relaciji, korelaciji između subjekta i objekta, gubi se, po Kentenovim rečima, ono Veliko Spolja, „ono Spolja koje nam nije bilo relativno, koje je bilo dato kao indiferentno svoje davanju da bi bilo ono što jeste, da bi kao takvo postojalo po sebi, mislili ga mi ili ne; ono Spolja koje mišljenje može da istraži s opravdanim osjećanjem da se nalazi na stranoj teritoriji - da se nalazi sasvim drugdje“" (Mejasu 2014, 18). 
Za Mejasua bitno je da postoji „izvestan tip entiteta bez mišljenja“, odnosno spekulativni materijalizam kakav Mejasu razvija „mora da tvrdi i da mišljenje nije nužno (nešto može biti bez mišljenja) i da mišljenje može da misli ono čega mora biti kada nema mišljenja“ (Mejasu 2014, 44).

Podela na svet, Zemlju i planetu izvedena je upravo imajući u vidu ove Mejasuove naznake o Velikom Spolja i korelacionizmu. Naime, svet je ono što postaje isključivo u vezi i kroz vezu sa čovekom, sve ono što je čovek stvorio, izgradio, proizveo, zamislio, konceptualizovao, ozvučio, oslikao, složio, itd. Svet je onaj objekt koji ne postoji izvan odnosa sa subjektom i koji subjekt stvara kroz taj odnos. Upravo se ovaj svet stvara na specifičan način koji nazivam bio-melo-političkim i bio-auralo-političkim. Pojam Zemlje se kreće u smeru Velikog Spolja, a razlika leži u odnosu između živog i neživog. Ovaj pojam označava Zemlju koja postoji nezavisno od čoveka i koja je živa. Njegova ključna razlika od sveta leži u njegovoj živoj indiferentnosti prema čoveku kao takvom. To je, zapravo, planetarni sloj koji možemo grubo nazvati biosfera. U svakom slučaju, i ovde postoje brojne konceptualizacije toga šta čini Zemlju/biosferu i na koji način to što je živo proizvodi zvuk i biva oblikovano zvukom kroz zoe-auralne-tehnologije, kako sam pokazao u prethodnom odeljku. Na kraju, Mejasuovo Veliko Spolja kao takvo označavam pojmom planete. Ako je i Zemlja kao biosfera bila ravnodušna prema još jednom životnom obliku među drugima koji je ljudska vrsta, onda pojam planete u ovom kontekstu, kao jedne od mnogih planeta u univerzumu, ide i korak dalje te ukazuje na indiferentnost prema životu kao takvom.

Indiferentnost planete prema čoveku, svemu ljudskom i, u krajnjoj instanci, svemu živom i životu kao takvom, najeksplicitnije teoretizuje Kler Kolbruk. $\mathrm{Za}$ nju, indiferentnost planete ogleda se u izumiranju čoveka kao vrste i pokušaju da se zamisli planeta posle čoveka, bez čoveka, ali i bez živih bića i života uopšte. Tačnije, Kolbrukova cilja na pokušaj mišljenja onoga prostora i vremena kada onoga što misli (i živi) nema. Paradoksalno, to znači da treba misliti odsustvo mišljenja, da treba misliti mišljenje u njegovom odsustvu i kroz njegovo odsustvo. Za Kolbrukovu, sve dosadašnje mišljenje bilo je zasnovano na kategorijama koje su proizvedene u skladu sa organskom slikom mišljenja. To znači da se mišljenje zasnivalo, pre svega, na afirmaciji živog, mnoštva, produktivnosti, drugog, čiste potencijalnosti i otvorene budućnosti. Ovakva slika mišljenja proizvodi i sliku čoveka kao organizma, ali i sliku planete kao sveta i Zemlje, kao „plavog klikera“ koji predstavlja zatvorenu samoobnavljajuću celinu koja se čak može smatrati i živom (Gaia). Ovakva slika sveta i Zemlje - kao samodovoljne celine - nastaje na temelju slike čoveka koja je organizovana u konstelaciji tri elemenata - od oka/suđenja, glasa/razuma i tela/rada. U najkraćem, reč je organizmu koji se (samo)održava. U tom pogledu, reč je o teološkoj formi figure autoreferentne, samostvarajuće žive forme koja nema svrhu izvan 
vlastite egzistencije (Colebrook 2014, 68-69), o čemu je već bilo reči u prethodnim odeljcima. Temporalnost koju ova slika sveta/Zemlje/čoveka proizvodi jeste linearna i cirkularna - linearna zbog pravolinijskog kretanja od rođenja do smrti, cirkularna jer je reč o zatvorenom kruženju samoobnavljanja vrste i života.

Planeta, kao ono što je radikalno drugačije od čoveka, živog i života mora se misliti na posve drugačijim temeljima, izvan slike mišljenja zasnovane na identitetu čoveka i sveta/Zemlje. To znači da treba iznaći figure života izvan tela i, još bitnije, tela izvan života (Colebrook 2014, 125-126). Planetu treba misliti kao telo koje je radikalno indiferentno prema kategorijama zasnovanim na živom. Preciznije, treba iskoračiti izvan okvira bio/zoe-ontologije i probati utemeljiti geontologiju. Planeta mora da postane radikalno nenastanjiva i negostoljubiva za život da bi se mislila kao planeta. Treba prekinuti organske vremenske linije, što, s jedne strane, znači uvesti pojam izumiranja vrsta, dok, s druge strane, znači uvesti temporalnost koja je apsolutno negostoljubiva za čoveka. Treba uvesti onu vremensku dimenziju koja istovremeno sobom nosi izumiranje ne samo čoveka već i živoga kao takvog. Time bi se budućnost počela konceptualizovati u planetarnim kategorijama namesto puko zemaljskim pojmovima zasnovanim na bio/zoe-ontologijama. To, takođe, znači da se budućnost misli kao lišena preživljavanja, kako čoveka, tako i svih drugih živih bića. Budućnost postaje radikalno zatvorena za adaptaciju i održanje živog. Budućnost nije više otvorena, gostoprimljiva i afirmativna, kako se konceptualizovala u relacionim teorijama, već je izvor apsolutnog prekida. U okvirima kategorija koje se odnose na ljudsku formu života, budućnost se zamišlja bez smislenog delanja, bez proizvodnje i bez rada - dakle, bez ikakve zajednice, ali ne ni samo bez zajednice, već bez ljudske forme života kao takve s obzirom na to da je ona određena ovim trima pojmovima.

Imajući u vidu to da se Zemlja i planeta, iz ove perspektive raskidanja odnosa sa čovekom, mogu smatrati srodnim pojmovima, može se postaviti pitanje njihovog odnosa. Ili, u kakvom odnosu stoje zoezvuk i geozvuk? Da li njihovo uodnošavanje otkriva nešto novo? Odgovor treba potražiti u postajanju-neživim neljudskog života, što ukazuje na, s jedne strane, sedimentaciju kao postajanje-fosilom, a s druge ekstrakciju kao postajanje-fosilnim gorivom. Najsažetije rečeno, odnos između zoezvuka i geozvuka očituje se kroz buku i to: saobraćaja koji se kreće na fosilna goriva, zvuk daljinskog grejanja u domovima koji su na njega priključeni jer toplane u Srbiji i dalje rade na fosilna goriva, zvuk sagorevanja prirodnog gasa u kuhinjama, ali i zvuk upotrebe plastičnih i drugih petrohemijskih proizvoda. U Srbiji se, primera radi, električna energija većim delom proizvodi u elektranama na ugalj, što umnogome proširuje opseg uodnošavanja zoezvuka i geozvuka. Tako je i zvuk brujanja kućnih aparata zvuk odnosa između zoezvuka i geozvuka, Zemlje i planete. U neku ruku, biozvuk je potpuno 
prožet odnosom zoezvuka i geozvuka i čak se može reći da biozvuk nastaje na temelju odnosa između neljudskog života koji je postao neživ i nežive planete, s obzirom na poreklo energije koja se koristi za stvaranje biozvuka. Ovaj odnos zoezvuka i geozvuka mogao bi se nazvati petrozvuk. Ovo, takođe, pokazuje i da se različita brazdanja imanencije zvučnog okruženja razlikuju u zavisnosti od lokalne, regionalne, državne i transnacionalne infrastrukture, naročito kada je reč o infrastrukturi koja se tiče petrokulture i energetike. U infrastrukturu, pored mreže za distribuciju energije i za njenu proizvodnju, u najširem mogućem smislu spadaju poštanski sistem, jezici i pisma, železnice, transokeanski kablovi, kalendari, vremenske zone, međunarodni poslovni standardi, kanalizacioni sistemi, mreža za kablovsku i optičku televiziju i internet, vodovodne cevi, vebsajtovi, klaud platforme i tako dalje (Likavčan 2019). To, pak, vodi zaključku da je glatki prostor imanencije uvek već izbrazdan i izlinijan jer linije i brazde zavise od ranije povučenih linija i brazdi koje, sa svoje strane, nastaju na osnovu nekih prethodnih. Glatkost imanencije je, ispostavlja se, čista virtuelnost. Reč je o geontologiji, koja se bavi izučavanjem sedimentacije slojeva od kojih je sačinjena apsolutna imanencija, a koja je ujedno i lišena živog, odnosno o ontosonografiji koja mapira postajanja bivstvujućih kroz i putem zvuka na ravni imanencije kada se uzme u obzir zvučni odnosi živog i neživog.

Zaključak

Biozvuk podrazumeva svet koji se proizvodi i održava kroz bio-melo-tehnologije i bio-auralne-tehnologije. Tu spada i nekrozvuk koji, kao intencionalno organizovani zvuk, pozvučava čovekov odnos sa planetom. Zoezvuk je zvuk živih bića, života kao takvog, Zemlje kao biosfere. Geozvuk imenuje zvučnost planete izvan njenih odnosa sa čovekom i životom uopšte. Ontosonografsko mapiranje postajanja kroz zvuk omogućilo je proizvodnju ovih pojmova i pokazalo da se kroz zvuk mogu otkriti odnosi između bivstvujućih koji su ostajali prikriveni kada im se pristupalo iz okulocentričnih perspektiva. Glavni uvid ovog rada zasniva se na uodnošavanju zoezvuka i geozvuka u vidu petrozvu$\mathrm{ka}$, na tome da se petrozvuk postavlja kao važan rezultat ovog uodnošavanja u okvirima antropocena. Drugim rečima, kada se posmatra iz perspetkive studija antropocena, može se reći da je petrozvuk ono što je najglasnije u našem svakodnevnom životu, to jest, da smo uvek već obavijeni petrozvučnim predelom.

Drugi bitni uvid jeste taj da se petrovukom ukida binarnost između Života i Neživota. Kako je petrozvuk rezultat uodnošavanja zoezvuka i geozvuka, rezultat postajanja-neživim neljudskog života i njegove eksploatacije u epohi antropocena, razlike između Života i Neživota u slučaju fosilnih goriva, petrohemijskih proizvoda i efekata koji njihova upotreba proizvodi, postaju nebitne. 
Tačnije, petrozvuku, ali i petrokulturama u celini, može se pristupati iz nebinarne perspektive. Umesto da posmatramo petrokulture na osnovu binarnosti Života i Neživota i, samim tim, na osnovu ontologije koja podrazumeva esencijalistički konceptualizovane parove suprotnosti, treba ih analizirati na imanentni način. Treba li im pristupiti radikalno imanentistički kao kod Fransoe Larijela ili apsolutno imanentistički kao kod Žila Deleza ostaje da se vidi u daljim istraživanjima. Bitan uvid za dalja istraživanja na ovom tragu jeste taj da petrozvuk ukida binarnost zoezvuka/Života i geozvuka/Neživota i da antropocen kao takav treba posmatrati kao imanenciju.

\section{Literatura}

Batut. 2018. „Informacija o aktuelnoj epidemiološkoj situaciji groznice Zapadnog Nila na teritoriji Republike Srbije u 2018. godini“" http://www.batut.org.rs/download/aktuelno/InformacijaoaktuelnojepidemioloskojsituacijiGZN14.8.2018.pdf

Chakrabarty, Dipesh. 2009. „The Climate of History: Four Theses“. Critical Inquiry 35(2): 197-222. DOI: https://doi.org/10.1086/59664010.1086/596640

Colebrook, Claire. 2014. Death of the PostHuman: Essays on Extinction, Vol. 1. Ann Arbor: Open Humanities Press.

Delez, Žil. 2011. „Imanencija: život...“. U Slike mišljenja Žila Deleza, uredila Kristina Bojanović, 10-12. Nikšić: Društvo filosofa Crne Gore.

Deleuze, Gilles i Félix Guattari. 2013. Kapitalizam i shizofrenija 2: Tisuću platoa. Zagreb: Sandorf i Mizantrop.

Duarte, Carlos M., Lucille Chapuis, Shaun P. Collin, Daniel P. Costa, Reny P. Devassy, Victor M. Eguiluz, Christine Erbe, Timothy A. C. Gordon, Benjamin S. Halpern, Harry R. Harding, Michelle N. Havlik, Mark Meekan, Nathan D. Merchant, Jennifer L. Miksis-Olds, Miles Parsons, Milica Predragovic, Andrew N. Radford, Craig A. Radford, Stephen D. Simpson, Hans Slabbekoorn, Erica Staaterman, Ilse C. Van Opzeeland, Jana Winderen, Xiangliang Zhang, Francis Juanes. 2021. „The soundscape of the Anthropocene ocean“. Science. Epub ahead publication. DOI: https://doi. org/10.1126/science.aba4658

Filipović, Andrija. 2019a. Conditio ahumana: Imanencija i ahumano u epohi Antropocena. Loznica: Karpos.

Filipović, Andrija. 2019b. „Three bugs in the city: urban ecology and multispecies relationality in postsocialist Belgrade". Contemporary Social Science. Epub ahead publication. DOI: https://doi.org/10.1080/21582041.2019.1667521

Fuko, Mišel. 1971. Riječi i stvari: Arheologija humanističkih nauka. Beograd: Nolit.

Fuko, Mišel. 2014. Bezbednost, teritorija, stanovništvo: Predavanja na Kolež de Fransu 1977-1978. Novi Sad: Mediterran Publishing.

Halberstam, Judith. 2011. „Keeping Time with Lesbians on Ecstasy“. In Queer Times, Queer Becomings, edited by E.L. McCallum and Mikko Tuhkanen, 333-344. Albany: State University of New York Press, Albany.

Likavčan, Lukáš. 2019. Introduction to Comparative Planetology. Ebook: Strelka Press. 
Mejasu, Kenten. 2014. Poslije konačnosti: Ogled o nužnosti kontingencije. Nikšić: Društvo filosofa Crne Gore.

Morton, Timothy. 2013. Hyperobjects: Philosophy and Ecology after the End of the World. Minneapolis: University of Minnesota Press.

Podraščanin, Maja. N/A. „Izborite se sa smrdibubama: trikovi i prirodna sredstva protiv smrdibuba(recepti)“. https://www.lepaisrecna.rs/moj-stan/srecni-dom/25550-izborite-se-sa-smrdibubama-trikovi-i-prirodna-sredstva-protiv-smrdibuba-recepti.html

Povinelli, Elizabeth A. 2016. Geontologies: A Requiem to Late Liberalism. Durham: Duke University Press.

Sadava, David E., David M. Hillis, H. Craig Heller, May Berenbaum. 2011. Life: The Science of Biology. Sunderland: Sinauer Associates Inc.

Szendy, Peter. 2012. Hits: Philosophy in the Jukebox. New York: Fordham University Press. Thacker, Eugene. 2010. After Life. Chicago: The University of Chicago Press.

Thacker, Eugene. 2011. In the Dust of this Planet: Horror of Philosophy Volume 1. Winchester: Zero Books. Kindle.

Tusa, Giovanbattista. 2020. „De-limitations. Of Other Earths“. Stasis: International journal in social and political philosophy and theory 9(1): 166-183. DOI: https://doi. org/10.33280/2310-3817-2020-9-1-166-183

Andrija Filipović Faculty of Media and Communications, University Singidunum, Belgrade, Serbia

Ontosonographic Maps: Toward a Theoretization of Soundscape Forms in the Anthropocene Epoch

This paper deals with the ways in which it is possible to conceptualize and map forms of soundscape in the epoch of the Anthropocene. After humans became a geological force, which is a role that used to be reserved for the planet itself, one can pose the question of how to understand this new condition through sound, as well as of the ways in which (re)production of the Anthropocene is heard and performed through sound. With the usage of the terms world, globe, Earth and the planet, a certain understanding of the human environment, current state of affairs, but also of the past and the future is projected. To these terms I connect different ways of production and reception of sound (bio-melo-technology, bio-aural-technology, zoe-aural-technology), and describe their mutual relations through the concepts of biosound, zoesound, necrosound, geosound, and petrosound. I produce this typology on the basis of ontosonographic methodology, and apply it to particular case studies such as popular music (k.d. lang, Lesbian on Ecstasy, My Bloody Valentine, black metal, noise), sounds insects 
make, and the noise produced by urban traffic. With the help of ontosonographic methodology I map forms of being and becoming through sound and as sound, which makes ontosonography a key concept for understanding the soundscape forms of the Anthropocene. Of decisive importance for understanding the Anthrpocene soundscape is the relation between biosound and geosound, which is produced through petrocultures understood as a multiplicity of practices of extraction and exploitation of fossil fuels. The dominant form of soundscape in the epoch of the Anthropocene is the petrosound. Also, a new way for understanding fossil fuels appears as a possibility, a way that is grounded in a non-binary way of thinking beyond the difference between Life and Non-Life. It remains as a task for further research whether to approach this petrocultural non-binarity through radical or absolute immanence or, perhaps, some other set of concepts more appropriate for the Anthropocene.

Keywords: Anthropocene, ontosonography, soundscape, planet, petrosound

Des cartes ontosonographiques: vers la théorisation des formes de l'environnement sonore à l'époque des anthropocènes

Dans ce travail je vais analyser les manières dont on peut conceptualiser et mapper les formes de l'environnement sonore à l'époque des anthropocènes. Par l'utilisation des notions comme monde, balle/globe, Terre et planète, est projetée une particulière compréhension de l'homme, de l'environnement, de l'état momentané des choses, mais aussi du passé et l'avenir. À ces concepts je rattache aussi les concepts qui nomment différentes manières de produire et de recevoir le son et leurs relations mutuelles - bio-son, zoe-son, nécro-son, géo-son et pétro-son. C'est cette typologie du son que j'élabore à l'appui de la méthodologie ontosonographique et que j'applique à des études de cas particuliers comme la musique populaire, le bourdonnement des inscectes et le bruit produit par le trafic. Il s'avère que c'est le rapport entre le bio-son et le géo-son, produit à travers la pétroculture définie comme une multitude de pratiques d'extraction et d'exploitation des combustibles fossiles, qui est d'une importance décisive pour la compréhension de l'environnement sonore anthropocène. La forme dominante ou la plus intense d'environnement sonore à l'époque des anthropocènes est le pétro-son.

Mots clés: Anthropocène, ontosonographie, environnement sonore, planète, pétro-son

Primljeno / Received: 8.02.2021

Prihvaćeno / Acceped: 10.03.2021

Етноантрополошки проблеми, н.с. год. 16 св. 2 (2021) 